\title{
New Breeding Techniques for Greenhouse Gas (GHG) Mitigation: Plants May Express Nitrous Oxide Reductase
}

\author{
Jordan J. Demone ${ }^{1,+}$, Shen Wan ${ }^{1,+}{ }^{\text {, Maryam Nourimand }}{ }^{1}$, Asbjörn Erik Hansen ${ }^{1}$, \\ Qing-yao Shu ${ }^{2} \mathbb{D}$ and Illimar Altosaar ${ }^{1, * \mathbb{D}}$ \\ 1 Department of Biochemistry, Microbiology, and Immunology, University of Ottawa, Ottawa, \\ ON K1H 8M5, Canada; jdemone@uottawa.ca (J.J.D.); swa2@uottawa.ca (S.W.); \\ mnourima@uottawa.ca (M.N.); aerik.hansen@gmail.com (A.E.H.) \\ 2 National Key Laboratory of Rice Biology, Institute of Crop Sciences, Zhejiang University, \\ Hangzhou 310058, China; qyshu@zju.edu.cn \\ * Correspondence: altosaar@uottawa.ca; Tel.: +1-613-562-5800 (ext. 6371) \\ + These authors contributed equally to this work.
}

Received: 4 August 2018; Accepted: 25 September 2018; Published: 27 September 2018

\begin{abstract}
Nitrous oxide $\left(\mathrm{N}_{2} \mathrm{O}\right)$ is a potent greenhouse gas (GHG). Although it comprises only $0.03 \%$ of total GHGs produced, $\mathrm{N}_{2} \mathrm{O}$ makes a marked contribution to global warming. Much of the $\mathrm{N}_{2} \mathrm{O}$ in the atmosphere issues from incomplete bacterial denitrification processes acting on high levels of nitrogen $(\mathrm{N})$ in the soil due to fertilizer usage. Using less fertilizer is the obvious solution for denitrification mitigation, but there is a significant drawback (especially where not enough $\mathrm{N}$ is available for the crop via $\mathrm{N}$ deposition, irrigation water, mineral soil $\mathrm{N}$, or mineralization of organic matter): some crops require high-N fertilizer to produce the yields necessary to help feed the world's increasing population. Alternatives for denitrification have considerable caveats. The long-standing promise of genetic modification for $\mathrm{N}$ fixation may be expanded now to enhance dissimilatory denitrification via genetic engineering. Biotechnology may solve what is thought to be a pivotal environmental challenge of the 21st century, reducing GHGs. Current approaches towards $\mathrm{N}_{2} \mathrm{O}$ mitigation are examined here, revealing an innovative solution for producing staple crops that can 'crack' $\mathrm{N}_{2} \mathrm{O}$. The transfer of the bacterial nitrous oxide reductase gene (nosZ) into plants may herald the development of plants that express the nitrous oxide reductase enzyme $\left(\mathrm{N}_{2} \mathrm{OR}\right)$. This tactic would parallel the precedents of using the molecular toolkit innately offered by the soil microflora to reduce the environmental footprint of agriculture.
\end{abstract}

Keywords: radiative warming; atmospheric phytoremediation; $\mathrm{N}_{2} \mathrm{O}$; nitrous oxide reductase; $\mathrm{N}_{2} \mathrm{OR}$; nosZ; fertilizer; crop breeding; transgenic; GHG

\section{Introduction-Nitrous Oxide Continues to Bloom Unabated}

Atmospheric nitrogen $(\mathrm{N})$ deposition is a pressing matter for climate change scientists concerned with the increasing danger that nitrous oxide $\left(\mathrm{N}_{2} \mathrm{O}\right)$, a noxious greenhouse gas (GHG), poses. Reactive nitrogen $(\mathrm{Nr})$ - ammonia $\left(\mathrm{NH}_{3}\right)$, nitrogen oxides $\left(\mathrm{NO}_{\mathrm{x}}\right)$, nitrates $\left(\mathrm{NO}_{3}{ }^{-}\right)$, and $\mathrm{N}_{2} \mathrm{O}$ - enters the biosphere from its original form of atmospheric $\mathrm{N}$ as at least three derivatives: gas, dry deposit, and precipitation (wet deposition) [1,2]. The sources of $\mathrm{N}_{2} \mathrm{O}$ are largely anthropogenic [3]. Many crops must receive $\mathrm{N}$-based fertilizer to reach yield targets, which is supplied by inorganic fertilizers and animal manure [4]. In an effort to boost the yield in crop staples like wheat, corn, and soybeans, farmers apply $\mathrm{N}$ fertilizers at rates and times that are not always properly synchronized with crop demand [5]. While crops thrive when fertilized, experimental analysis has demonstrated that up to 
$40 \%$ of fertilizer $\mathrm{N}$ can be lost via leaching [6,7]. Other routes of $\mathrm{N}$ loss include soil erosion, $\mathrm{NH}_{3}$ volatilization and oxidation, and bacterial/fungal denitrification [8], although $\mathrm{N}$ losses through $\mathrm{NH}_{3}$ volatilization are higher than those via $\mathrm{N}$ leaching [9]. Around $62 \%$ of total global $\mathrm{N}_{2} \mathrm{O}$ issues from natural and agricultural soils, and the bulk of this production, mainly results from the processes of bacterial nitrification and denitrification [10].

$\mathrm{Nr}$ compounds enter the atmosphere through biological processes, but the invention of the Haber-Bosch process in 1908 was a critical moment for the sudden increase in Nr and GHG production globally [11]. This process of artificial N-fixation allowed for the large-scale reduction of $\mathrm{N}_{2}$ to $\mathrm{NH}_{3}$, producing massive amounts of synthetic $\mathrm{N}$-based fertilizers that supported dramatic increases in high-yield farming [12]. This process now accounts for $80 \%$ of anthropogenic $\mathrm{N}$-fixation (the remaining $20 \%$ resulting from combustion [13], with anthropogenic N-fixation in turn accounting for $60 \%$ of global N-fixation [14]). Haber-Bosch remains the industry standard synthetic $\mathrm{N}$ fertilizer today and as a result, has contributed to the $\sim 2 \%$ increase in atmospheric levels of $\mathrm{N}_{2} \mathrm{O}[15,16]$. This effect is also magnified by the global emissions of $\mathrm{N}_{2} \mathrm{O}$ produced by fossil fuel combustion [17] and the natural ability of legumes to fix $\mathrm{N}$ through symbiotic relationships with soil bacteria [18].

$\mathrm{N}_{2} \mathrm{O}$ is the third most prevalent GHG, behind carbon dioxide $\left(\mathrm{CO}_{2}\right)$ and methane $\left(\mathrm{CH}_{4}\right)$ [19]. The concentration of this gas in the atmosphere has been steadily increasing since the early 1900s (Figure 1), and it is 265 times more radiative than $\mathrm{CO}_{2}$ [19]. $\mathrm{N}_{2} \mathrm{O}$ also has an atmospheric lifetime of 121 years; by comparison, $\mathrm{CH}_{4}$ has an atmospheric lifetime of only 12 years, but $\mathrm{CO}_{2}$ also has a long half-life and can take anywhere from 20-200 years to be absorbed by the ocean [19], compounding the 'greenhouse gas' effect. Since chlorofluorocarbons (CFCs) were banned in 1989, $\mathrm{N}_{2} \mathrm{O}$ has become the leading cause of ozone layer depletion [20].

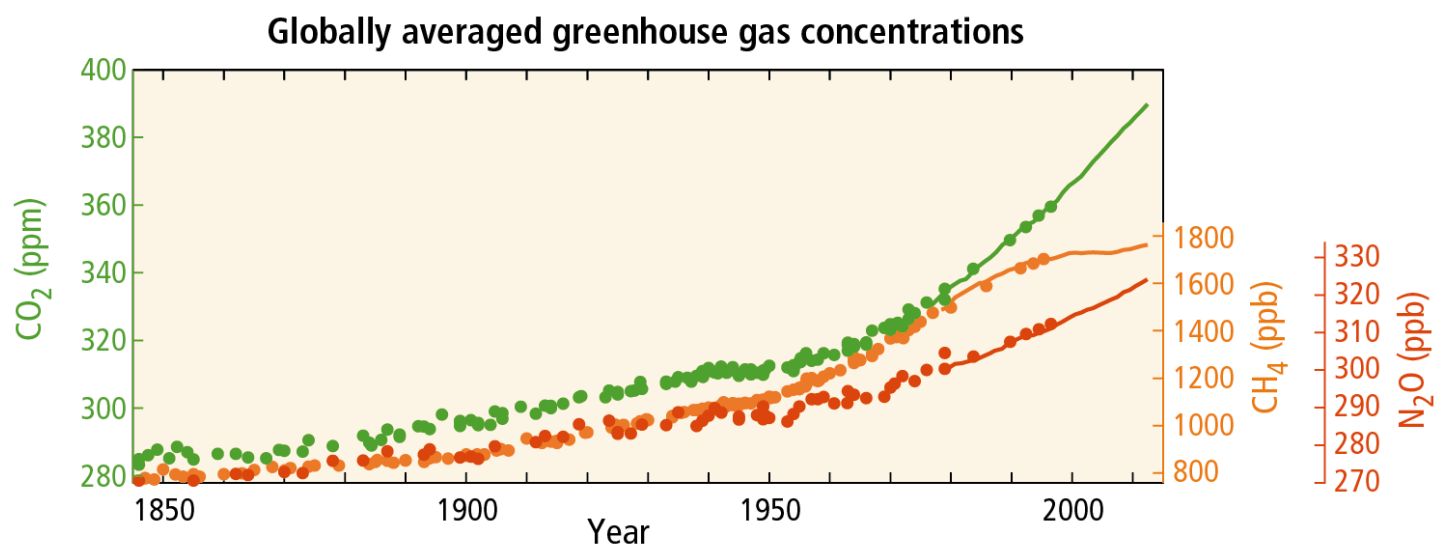

Figure 1. GHG levels since 1850. The green line represents the increase in $\mathrm{CO}_{2}$ concentration since 1850; the orange line represents the increase in $\mathrm{CH}_{4}$ concentration since 1850; lastly, the red line represents the increase in $\mathrm{N}_{2} \mathrm{O}$ since 1850 [19].

$\mathrm{N}_{2} \mathrm{O}$ emission results from the coupled oxidation and reduction of $\mathrm{N}$ performed by heterotrophic [21] (and some autotrophic) soil proteobacteria: (1) the nitrification pathway is catalyzed by autotrophs (Nitrosomonas spp. and other genera [22]) and also heterotrophs, and involves the oxidation of $\mathrm{NH}_{3}$ /ammonium $\left(\mathrm{NH}_{4}{ }^{+}\right)$to nitrite $\left(\mathrm{NO}_{2}{ }^{-}\right)$[23] and nitric oxide (NO) [24]), which is followed by the oxidation of $\mathrm{NO}_{2}{ }^{-}$to $\mathrm{NO}_{3}{ }^{-}$by Nitrobacter spp. [25]; and (2) the denitrification pathway, whereby $\mathrm{NO}_{3}{ }^{-}$is reduced to $\mathrm{N}_{2} \mathrm{O}$ and ultimately inert $\mathrm{N}_{2}$ gas [26]. As many as a third of soil bacterial species [27] lack the nos $\mathrm{Z}$ gene that reduces $\mathrm{N}_{2} \mathrm{O}$ to inert $\mathrm{N}_{2}$ [28], which leads to a sizeable amount of incomplete denitrification reactions and the subsequent buildup of $\mathrm{N}_{2} \mathrm{O}$ since it is an obligate intermediate [29]. This $\mathrm{N}_{2} \mathrm{O}$ diffuses out of the soil and into the atmosphere, contributing to the greenhouse effect, contaminating water, and leading to serious human health implications $[30,31]$. 


\section{Combating GHGs: Current $\mathrm{N}_{2} \mathrm{O}$ Mitigation Strategies and Limitations}

Demands for crop-borne food must be met, and so researchers must address the hazards of $\mathrm{N}$-based fertilizers [32]. There are multiple $\mathrm{N}_{2} \mathrm{O}$ mitigation strategies either currently in commercial use or in development (summarized in Table 1).

Table 1. Summary of current $\mathrm{N}_{2} \mathrm{O}$ mitigation strategies.

\begin{tabular}{|c|c|c|c|}
\hline Strategy & Mechanism of Action & Pros & Cons \\
\hline $\begin{array}{l}\text { (1) Conservation tillage } \\
\text { and crop rotation [33] }\end{array}$ & $\begin{array}{l}\text { Tillage, rotation of } \mathrm{N} \text {-fixing } \\
\text { crops, cover cropping [33] }\end{array}$ & $\begin{array}{l}\text { Prevent } \mathrm{NH}_{3} \\
\text { volatilization and } \\
\text { eventual } \mathrm{N}_{2} \mathrm{O} \text { emissions } \\
{[34,35]}\end{array}$ & $\begin{array}{l}\text { Unreliable } \mathrm{N}_{2} \mathrm{O} \text { mitigation } \\
{[36,37] \text {. Yield reduction [38]. }} \\
\text { Not effective at scrubbing } \\
\mathrm{N}_{2} \mathrm{O} \text { from the air }\end{array}$ \\
\hline $\begin{array}{l}\text { (2) Best management } \\
\text { practices (BMPs) [39] }\end{array}$ & $\begin{array}{l}\text { Correct source, placement, } \\
\text { time, and rate of fertilization } \\
\text { [40]. Proper irrigation } \\
\text { (fertigation) [41] }\end{array}$ & $\begin{array}{l}\text { Proven to reduce } \mathrm{N}_{2} \mathrm{O} \\
\text { emissions [41] and other } \\
\mathrm{N} \text { losses [42] }\end{array}$ & Technical constraints [43] \\
\hline (3) EENFs [44] & $\begin{array}{l}\text { Multiple types: stable, } \\
\text { short-release (SRFs), and } \\
\text { constant-release (CRFs); rely } \\
\text { on enrichment of chemical } \\
\text { inhibitors or coated } \\
\text { N-compounds that are } \\
\text { released into the soil over a } \\
\text { period of time [45]; urease } \\
\text { inhibitors (UIs) [46] }\end{array}$ & $\begin{array}{l}\text { Proven to reduce } \mathrm{N}_{2} \mathrm{O} \\
\text { emissions }[47,48]\end{array}$ & $\begin{array}{l}\text { Inconsistent yields from year } \\
\text { to year [48]. More expensive } \\
\text { than standard } \mathrm{N} \text { fertilizers } \\
\text { [49]. Long lifetime of } \\
\mathrm{N} \text {-compounds in soil can lead } \\
\text { to } \mathrm{NH}_{3} \text { volatilization [50,51]. } \\
\mathrm{Not}_{\text {effective at scrubbing }} \\
\mathrm{N}_{2} \mathrm{O} \text { from the air }\end{array}$ \\
\hline $\begin{array}{l}\text { (4) Synthetic } \mathrm{N}_{2} \mathrm{O} \\
\text { mitigators }\end{array}$ & $\begin{array}{l}\text { SNIs suppress activity of } \\
\text { nitrifying bacteria in the soil } \\
\text { [52]. SDIs operate by } \\
\text { unknown mechanism } \\
{[44,53,54]}\end{array}$ & $\begin{array}{l}\text { SNIs and SDIs reduce } \\
\mathrm{N}_{2} \mathrm{O} \text { emissions }[52,54]\end{array}$ & $\begin{array}{l}\text { Effectiveness depends on } \\
\text { environmental conditions, } \\
\text { prefer low temperature and } \\
\text { sandy soils [55]. Not effective } \\
\text { at scrubbing } \mathrm{N}_{2} \mathrm{O} \text { from the air }\end{array}$ \\
\hline $\begin{array}{l}(5) \text { Biological } \mathrm{N}_{2} \mathrm{O} \\
\text { mitigators }\end{array}$ & $\begin{array}{l}\text { BNIs suppress activity of } \\
\text { nitrifying bacteria in the soil } \\
\text { by releasing compounds that } \\
\text { inhibit } \mathrm{NH}_{3} \text {-oxidizing } \\
\text { pathways [56]. BDIs inhibit } \\
\text { nitrate reductase to inhibit } \\
\mathrm{N}_{2} \mathrm{O} \text { production [57] }\end{array}$ & $\begin{array}{l}\text { BNIs demonstrated to } \\
\text { reduce } \mathrm{N}_{2} \mathrm{O} \text { emission } \\
\text { [56]; BDIs inhibit } \\
\text { denitrification and can } \\
\text { conceivably mitigate } \\
\mathrm{N}_{2} \mathrm{O} \text { emissions [57] }\end{array}$ & $\begin{array}{l}\text { BNI-exuding plants must be } \\
\text { grown in rotation with other } \\
\text { crops [58]. Little work done on } \\
\text { BDI-exuding plants [57]. Not } \\
\text { effective at scrubbing } \mathrm{N}_{2} \mathrm{O} \\
\text { from the air }\end{array}$ \\
\hline $\begin{array}{l}\text { (6) Microbial } \\
\text { bioremediation }\end{array}$ & $\begin{array}{l}\text { Proper water table } \\
\text { management to facilitate } \\
\text { growth of rhizobia [59]; } \\
\text { inoculation of plant roots } \\
\text { with genetically modified } \\
\mathrm{N}_{2} \mathrm{O} \text {-cracking rhizobia }[60,61]\end{array}$ & $\begin{array}{l}\text { Enables plants to } \\
\text { degrade contaminants in } \\
\text { the soil; } \mathrm{N}_{2} \mathrm{O} \text {-cracking } \\
\text { rhizobia demonstrated to } \\
\text { reduce } \mathrm{N}_{2} \mathrm{O} \text { emissions } \\
{[60,61]}\end{array}$ & $\begin{array}{l}\text { Most effective on crops that } \\
\text { naturally cultivate a } \\
\text { rhizosphere of } \mathrm{N}_{2} \mathrm{O} \text {-reducing } \\
\text { [62] microorganisms, i.e., } \\
\text { soybean [63]. Not effective at } \\
\text { scrubbing } \mathrm{N}_{2} \mathrm{O} \text { from the air }\end{array}$ \\
\hline (7) Rhizosecretion & $\begin{array}{l}\text { Transformation of amenable } \\
\text { crops to express recombinant } \\
\text { bacterial proteins that reduce } \\
\mathrm{N}_{2} \mathrm{O} \text { [64] }\end{array}$ & $\begin{array}{l}\text { Plants that secrete } \\
\mathrm{N}_{2} \mathrm{O} \text {-cracking enzyme } \\
\text { could target } \mathrm{N}_{2} \mathrm{O} \text { in soil } \\
\text { [64] }\end{array}$ & $\begin{array}{l}\text { Plant transformation is a } \\
\text { time-consuming process [65]. } \\
\text { Bacterial proteins may not } \\
\text { function efficiently in } \\
\text { heterologous hosts [66]. Not } \\
\text { effective at scrubbing } \mathrm{N}_{2} \mathrm{O} \\
\text { from the air }\end{array}$ \\
\hline $\begin{array}{l}\text { (8) Atmospheric } \\
\text { phytoremediation }\end{array}$ & $\begin{array}{l}\text { Transformation of amenable } \\
\text { crops with genes expressing } \\
\text { recombinant bacterial } \\
\text { proteins that reduce } \mathrm{N}_{2} \mathrm{O} \text { [67] }\end{array}$ & $\begin{array}{l}\text { Arm crops and other } \\
\text { plant species to mop up } \\
\mathrm{N}_{2} \mathrm{O} \text { in the atmosphere } \\
\text { [67], including } \mathrm{N}_{2} \mathrm{O} \\
\text { emitted by other } \\
\text { non-agricultural sources }\end{array}$ & $\begin{array}{l}\text { Plant transformation is a } \\
\text { time-consuming process [65]. } \\
\text { Bacterial genes may not } \\
\text { function in a heterologous } \\
\text { system [66]. Not yet } \\
\text { experimentally validated via } \\
\text { gas analysis }\end{array}$ \\
\hline
\end{tabular}

BDI, biological denitrification inhibitor; BNI, biological nitrification inhibitor; EENFs, enhanced efficiency nitrogen fertilizers; SDI, synthetic denitrification inhibitor; SNI, synthetic nitrification inhibitor. 
(1) Conservation tillage and crop rotation. Mechanical incorporation (tillage) of N-based fertilizer into the soil may also be effective [68], but this is affected by many other parameters, such as the method of $\mathrm{N}$ application (i.e., broadcast vs surface urea ammonium nitrate). These techniques also result in a reduced yield [38]. Conservation tillage increases $\mathrm{N}_{2} \mathrm{O}$ emissions compared with no-till and conventional tillage techniques using broadcast application, while tillage in general does not reduce $\mathrm{N}_{2} \mathrm{O}$ emissions produced from surface urea ammonium nitrate-treated fields [69]. Other studies have shown that conservation tillage reduces $\mathrm{N}_{2} \mathrm{O}$ emissions [70], underscoring the lack of reliability of this $\mathrm{N}$ management technique [36,37]. Crop rotation with $\mathrm{N}$-acquisitive plant species can also reduce $\mathrm{N}_{2} \mathrm{O}$ emissions following the application of high $\mathrm{N}$-fertilizer treatment [33]; cover cropping can also control $\mathrm{N}_{2} \mathrm{O}$ emissions, but the results are often variable and in some cases can increase $\mathrm{N}_{2} \mathrm{O}$ emissions [71];

(2) Best management practices (BMP) [39]. Such nitrogen use efficiency techniques are myriad and involve simple steps such as proper fertilizer placement, timing of fertilizer application, the right type of $\mathrm{N}$-compound, and so on. Others involve the proper incorporation of N-compounds into the soil so that they may be taken up by the plant more effectively and will be less likely to volatilize [72]. Fertigation, a technique involving careful irrigation of fields following the application of $\mathrm{N}$ fertilizer, is effective at mitigating $\mathrm{N}_{2} \mathrm{O}$ emissions [41]. Such knowledge-based $\mathrm{N}$ management practices have been shown to be effective at both increasing crop yield and reducing immediate $\mathrm{N}_{2} \mathrm{O}$ emissions [73], but some approaches may also increase $\mathrm{N}_{2} \mathrm{O}$ production in the long term [55]. Their effectiveness also depends heavily on proper practices put in place by the farmers themselves, which requires proper training [43];

(3) Fertilizer management using enhanced efficiency nitrogen fertilizers (EENFs). These fertilizer cocktails are concocted in such a way that they prevent the volatilization of $\mathrm{NH}_{3}$ and inhibit nitrification/denitrification [46]. EENFs generally fall into one of three categories: (a) stabilized fertilizers, which contain nitrification and/or urease inhibitors; (b) slow-release fertilizers (SRFs), whereby the N source in the fertilizer is released over time from encapsulated granules, although the release rates can be variable; and (c) controlled-release fertilizers (CRFs), where the release rate is constant [45]. Urease inhibitors (UIs) are also a common EENF component. N-(n-butyl) thiophosphoric triamide (NBPT), phenylphosphorodiamidate (PPD), and hydroquinone are used worldwide and act by inhibiting the bacterial hydrolysis of urea into $\mathrm{NH}_{3}$ in fertilizer $[46,74,75]$. UIs are typically used in conjunction with nitrification inhibitor (NIs) for maximum effectiveness [76,77], but NBPT alone can reduce $\mathrm{N}_{2} \mathrm{O}$ emissions from $\mathrm{N}$-treated soil [78]. There is controversy regarding the effectiveness of EENFs; while reductions in $\mathrm{N}_{2} \mathrm{O}$ emissions from the soil have been recorded $[47,48]$, recent studies have shown that crop yields are only marginally higher when EENFs are used in place of standard $\mathrm{N}$ fertilizers [79]. Those studies that demonstrated reduced $\mathrm{N}_{2} \mathrm{O}$ emissions also reported inconsistent results from year to year [50]. Questionable effectiveness notwithstanding, EENFs are more expensive than conventional N-containing fertilizers and require special handling and storage $[49,80]$, which are all features that make these fertilizers less attractive to farmers;

(4) Synthetic $\mathbf{N}_{2} \mathbf{O}$ mitigators. Synthetic nitrification inhibitors (SNIs) and UIs are both used in EENFs and can be applied to crops in conjunction with standard $\mathrm{N}$ fertilizer. NIs inhibit the activity of Nitrosomonas to block the nitrification of $\mathrm{N}$ in fertilizer (the oxidation of $\mathrm{NH}_{3}$ to hydroxylamine via ammonia monooxygenase (AMO)) [23,52]. The efficacy of the inhibitors is also dependent on environmental conditions, as they are unstable; 3,4-dimethylpyrazole phosphate (DMPP), for example, exhibited reduced activity in hot, dry conditions [81]. The use of these inhibitors can also lead to less than desirable results: DMPP and 3-methylpyrazole 1,2,4-triazole $(3 \mathrm{MP}+\mathrm{TZ})$ have been shown to increase $\mathrm{N}_{2} \mathrm{O}$ emissions in vegetable crop systems, as the inhibitors promote the buildup of $\mathrm{N}$ in the fraction of the soil most available to bacteria during the breakdown of vegetative matter. Synthetic denitrification inhibitors (SDIs) suppress denitrification via unknown mechanisms [82], although some are known to inhibit the activity of fungal copper reductase [83]. 
SDIs nitrapyrin [84], toluidine [54], and acetylene [44] all effectively mitigate $\mathrm{N}_{2} \mathrm{O}$ emission, albeit with toxic side-effects [55], and they do not technically inhibit nitric oxide reductase;

(5) Biological $\mathbf{N}_{2} \mathrm{O}$ mitigators. This category is comprised of compounds produced by plants that inhibit enzymes in either the bacterial nitrification or denitrification pathway. The exploitation of such inhibiting root exudates is another intriguing approach towards $\mathrm{N}_{2} \mathrm{O}$ mitigation [82]. Biological nitrification inhibitors (BNIs) are compounds that block the activity of $\mathrm{NO}_{2}{ }^{-}$producing enzymes. The roots of the tropical grass Brachiaria humidicola exude brachialactone, a compound that can mitigate $\mathrm{N}_{2} \mathrm{O}$ emission from soil [85]. Attempts at developing BNI-producing cultivated wheat by crossing Triticum aestivum with BNI-producer Leymus racemosus, a wild wheat, have imparted some BNI activity, but also made the lines susceptible to rust infection [86]. The use of BNIs as an effective $\mathrm{N}_{2} \mathrm{O}$ mitigator is also severely limited by the fact that the enactor of nitrification is a plant itself and cannot be applied to growing crops, although growing $B$. humidicola in rotation with maize saw a four-fold increase in yield [87]. Biological denitrification inhibitors (BDIs) are a relatively new discovery. Currently, the only example of such an inhibitor is the procyanidin produced by the invasive Fallopia spp. (Asian knotweed). This compound has been demonstrated to be an allosteric inhibitor of Pseudomonas brassicacearum nitrate reductase and while it does reduce denitrification in the soil, it has not yet been proven to mitigate $\mathrm{N}_{2} \mathrm{O}$ levels [57];

(6) Microbial bioremediation [88]. The success of $\mathrm{N}$ fertilizer management techniques and proper irrigation is largely due to the creation of a microsphere conducive to denitrifying bacteria flourishing [89]. Proper water table management techniques can promote the growth of $\mathrm{N}_{2} \mathrm{O}$-cracking bacteria in the soil and reduce $\mathrm{N}_{2} \mathrm{O}$ emissions from the managed soil regions [59]. Another type of microbial bioremediation takes advantage of the ability of certain bacterial species to inhabit the root nodules of leguminous crops. Field peas [62], broad beans [90], and soybean [63] house bacteria (or rhizobia) that fix $\mathrm{N}$ and, unfortunately, also produce $\mathrm{N}_{2} \mathrm{O}$ gas. While maintaining the rhizosphere, $\mathrm{N}_{2} \mathrm{O}$ emissions can be mitigated by inoculating the roots of leguminous plants with rhizobia modified to express higher levels of a bacterial $\mathrm{N}_{2} \mathrm{O}$-cracking enzyme [60]. Genetically engineered strains of Bradyrhizobium japonicum have been used to inoculate the roots of soybean and reduced $\mathrm{N}_{2} \mathrm{O}$ emissions [61]. Needless to say, this method is far more effective on crops that naturally cultivate a rhizosphere of $\mathrm{N}_{2} \mathrm{O}$-reducing microorganisms. It is also another technique that cannot target atmospheric $\mathrm{N}_{2} \mathrm{O}$;

(7) Rhizosecretion. This is a biotechnology-based approach, involving the transformation of amenable crop plants with genes expressing recombinant bacterial proteins that reduce $\mathrm{N}_{2} \mathrm{O}$ by secreting $\mathrm{N}_{2} \mathrm{O}$-cracking enzymes $[64,91]$. Plants can be engineered to express proteins under the control of promoters that induce hairy root formation in plants. This rooting response results from the presence of the rolABCD genes from Agrobacterium rhizogenes, the bacterium that induces hairy root disease [92]. The rhizosecretion expression system harnesses the ability of $A$. rhizogenes to both target gene expression to the roots and to increase root biomass, subsequently increasing the amount of recombinant protein secreted into the soil [91]. Tobacco plants expressing a bacterial $\mathrm{N}_{2} \mathrm{O}$-cracking enzyme tagged for secretion under the control of the A. rhizogenes rolD promoter have been successful in demonstrating reducing activity [64,93]. Gas analysis was not performed to confirm that these plants mitigated $\mathrm{N}_{2} \mathrm{O}$ emission. Ultimately, this approach arrives at a similar problem as other 'rhizoremediative' techniques: the $\mathrm{N}_{2} \mathrm{O}$-reducing ability of such a transgenic plant would be limited to the rhizosphere. This system would not have access to the bulk of $\mathrm{N}_{2} \mathrm{O}$ gas, much of which comes from other sources;

(8) Atmospheric phytoremediation using genetically engineered plants. The potential of transgenic plants for environmental phytoremediation is well-documented: several fungal and bacterial oxidoreductases have been functionally expressed in plants as phytoremediation strategies including pentaerythritol tetranitrate reductase [94], mercuric reductase [95], and arsenate reductase [96]. This type of plant-based decontamination strategy provides advantages, 
such as stable cultivation and control of the remediant organism and atmospheric exposure of the gas-cracking enzyme [97].

Atmospheric phytoremediation may ameliorate problems created by the other $\mathrm{N}_{2} \mathrm{O}$ mitigation strategies described. The concept here is to develop crops with the ability to "crack" $\mathrm{N}_{2} \mathrm{O}$ in both the soil and the atmosphere by incorporating the bacterial nos $\mathrm{Z}$ gene into their genomes. This gene encodes the nitrous oxide reductase enzyme $\left(\mathrm{N}_{2} \mathrm{OR}\right)$, an oxidoreductase that catalyzes the removal of $\mathrm{N}_{2} \mathrm{O}$ from the atmosphere, a process performed naturally by both denitrifying and non-denitrifying bacteria in the soil [98]. While conventional $\mathrm{N}_{2} \mathrm{O}$ mitigation strategies aim to control $\mathrm{N}_{2} \mathrm{O}$ production at earlier stages in the nitrification/denitrification pathway, this approach will target the atmospheric sum of $\mathrm{N}_{2} \mathrm{O}$ emitted by all sources (Figure 2).

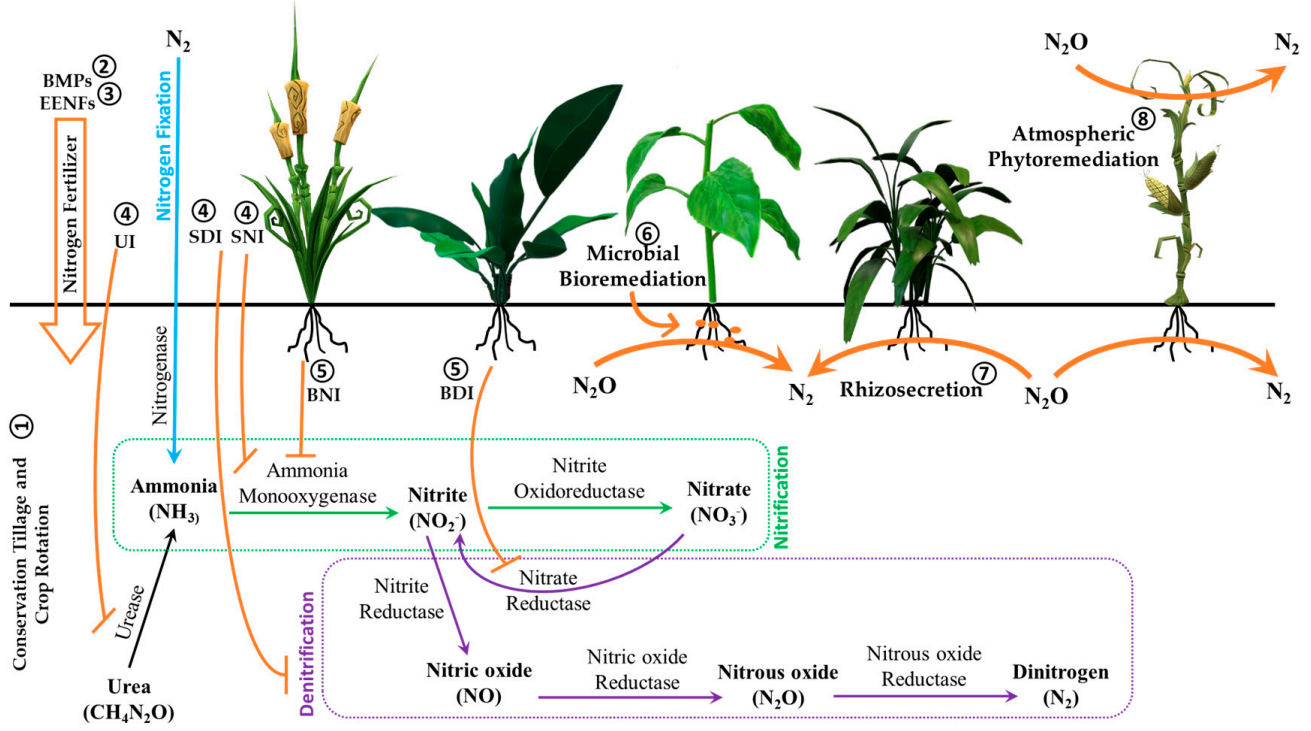

Figure 2. Nitrification-denitrification pathway and overview of current $\mathrm{N}_{2} \mathrm{O}$ mitigation strategies. Orange arrows and lines show eight $\mathrm{N}_{2} \mathrm{O}$ mitigation strategies described in Table 1. Green arrows show nitrification and purple arrows represent denitrification reactions. BDI, biological denitrification inhibitor; BMPs, best management practices; BNI, biological nitrification inhibitor; EENFs, enhanced efficiency nitrogen fertilizers; SDI, synthetic denitrification inhibitor; SNI, synthetic nitrification inhibitor; UI, urease inhibitor. O Encircled numbers refer to Table 1 strategies.

\section{Nitrous Oxide Reductase-An Orphaned Soil Protein?}

The nosZ gene can be categorized as either 'clade I' or 'clade II' based on sequence and nos operon organization, including the lack of an accessory nos $R$ gene in the clade II members [99]. Clade II nos $Z$ genes are also known as 'atypical' nos genes since they are found in non-denitrifying bacterial species. The $\mathrm{N}_{2} \mathrm{OR}$ enzyme that the clade II gene encodes catalyzes the same reaction performed by the clade I-encoded enzyme, but has a higher affinity for $\mathrm{N}_{2} \mathrm{O}$ [100], an important factor to consider when conceptualizing the development of an nosZ-expressing plant.

$\mathrm{N}_{2} \mathrm{OR}$ is a multi-copper protein encoded by the nos $Z$ gene (which is accompanied by an operon cluster of additional genes (nosRDFYL) [101]) and is the only enzyme that can catalyze the conversion of $\mathrm{N}_{2} \mathrm{O}$ into $\mathrm{N}_{2}$. The first active $\mathrm{N}_{2} \mathrm{OR}$ was characterized from the soil bacterium Pseudomonas stutzeri and similar enzyme structures were resolved in bacterial species Marinobacter hydrocarbonoclasticus (formerly Pseudomonas nautica) (Figure 3), Achromobacter cyclocastes, and Paracoccus denitrificans. $\mathrm{N}_{2} \mathrm{OR}$ is a head-to-tail homodimer and each monomer contains two domains: an electron transferring domain (binuclear $\mathrm{Cu}_{\mathrm{A}}$ centre) and a catalytic domain (tetranuclear $\mathrm{Cu}_{\mathrm{Z}}$ centre) [102]. There is some variability between the species regarding $\mathrm{Cu}_{\mathrm{Z}}$ bridging and cupric coordination in the catalytic centre, suggesting that $\mathrm{N}_{2} \mathrm{OR}$ substrate binding is species-specific. Regardless, the catalytic mechanism of $\mathrm{N}_{2} \mathrm{O}$ reduction in $\mathrm{N}_{2} \mathrm{OR}$ is still unclear [103]. 


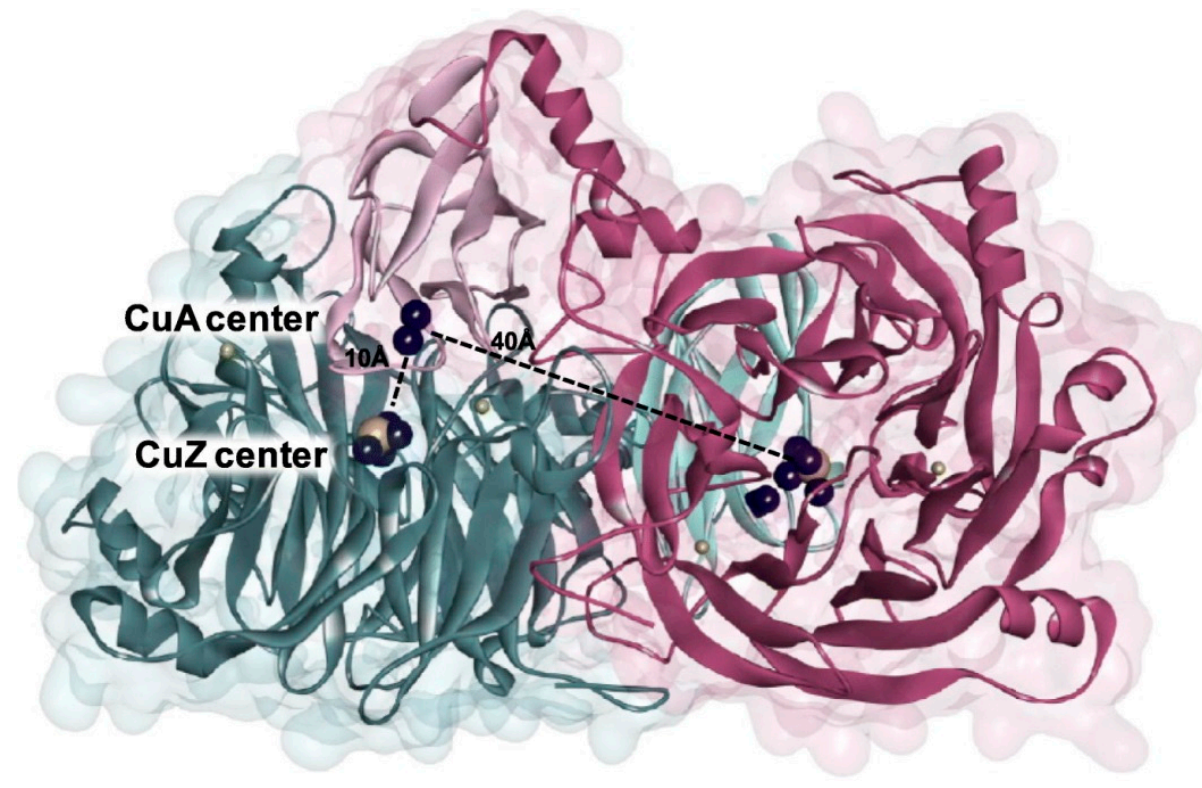

Figure 3. Structure of Marinobacter hydrocarbonoclasticus nitrous oxide reductase $\left(\mathrm{N}_{2} \mathrm{OR}\right)$ homodimer. $\mathrm{N}_{2} \mathrm{OR}$ is organized as a head-to-tail homodimer. Monomers are coloured differently so that they can be distinguished. In both monomers, the N-terminal domain is dark-coloured. The N-terminal domain forms a seven-bladed $\beta$-propeller fold that coordinates the catalytic tetranuclear active site $\mathrm{Cu}_{\mathrm{Z}}$ through seven histidine residues at its hub. The $\mathrm{C}$-terminal domain forms a cupredoxin fold and binds the dinuclear mixed-valent $\mathrm{Cu}_{\mathrm{A}}$ centre [104].

The proven ability of $\mathrm{N}_{2} \mathrm{OR}$ to "crack" the $\mathrm{N}_{2} \mathrm{O}$ molecule raises the question of why the protein has not yet been incorporated into a commercially available transgenic cropping choice for environmentally motivated producers and small-plot farmers. Work has been done on this gene and its potential role in plant biotechnology since it was originally isolated in 1998 from the anaerobic soil bacterium $A$. cyclocastes $[105,106]$, but it has yet to be converted into a commercially valuable tool. In this sense, $\mathrm{N}_{2} \mathrm{OR}$ may be considered an "orphaned" protein, neglected among a veritable molecular toolkit of genes in the soil microflora $[107,108]$. Such forays into integrating soil and air sciences are demonstrative of the possibilities of what the soil microbiome offers biotechnologists [27]; it has already been discussed regarding the $\mathrm{N}$-management possibilities offered by the microbiome and the current practice of 'bioprospecting' is also revealing a plethora of beneficial bacterial products, which is only accelerating thanks to whole-system approaches involving computational analyses [109].

Web of Science reports that between 1900 and 1991, there are no records binned under the combined topics "nitrous oxide reductase" and "microb". The scientific literature blossomed from its first occurrence of 1992 to the present day, witnessing at least 175 publications dealing with the science of this important enzyme in our total environment. The scientific community waited until 1996 to start discussing denitrification in a plant context, according to these same search terms. With the search terms "nitrous oxide reductase" and "plant", the scientific record shows that soil microbiologists have taken a growing interest in the movement of $\mathrm{N}$ into the atmosphere (Figure 4). It is encouraging to note that in the same time period, the linkage between $\mathrm{N}_{2} \mathrm{OR}$ and climate began its nascent phase. 
Publications by key word vs 'nitrous oxide reductase'

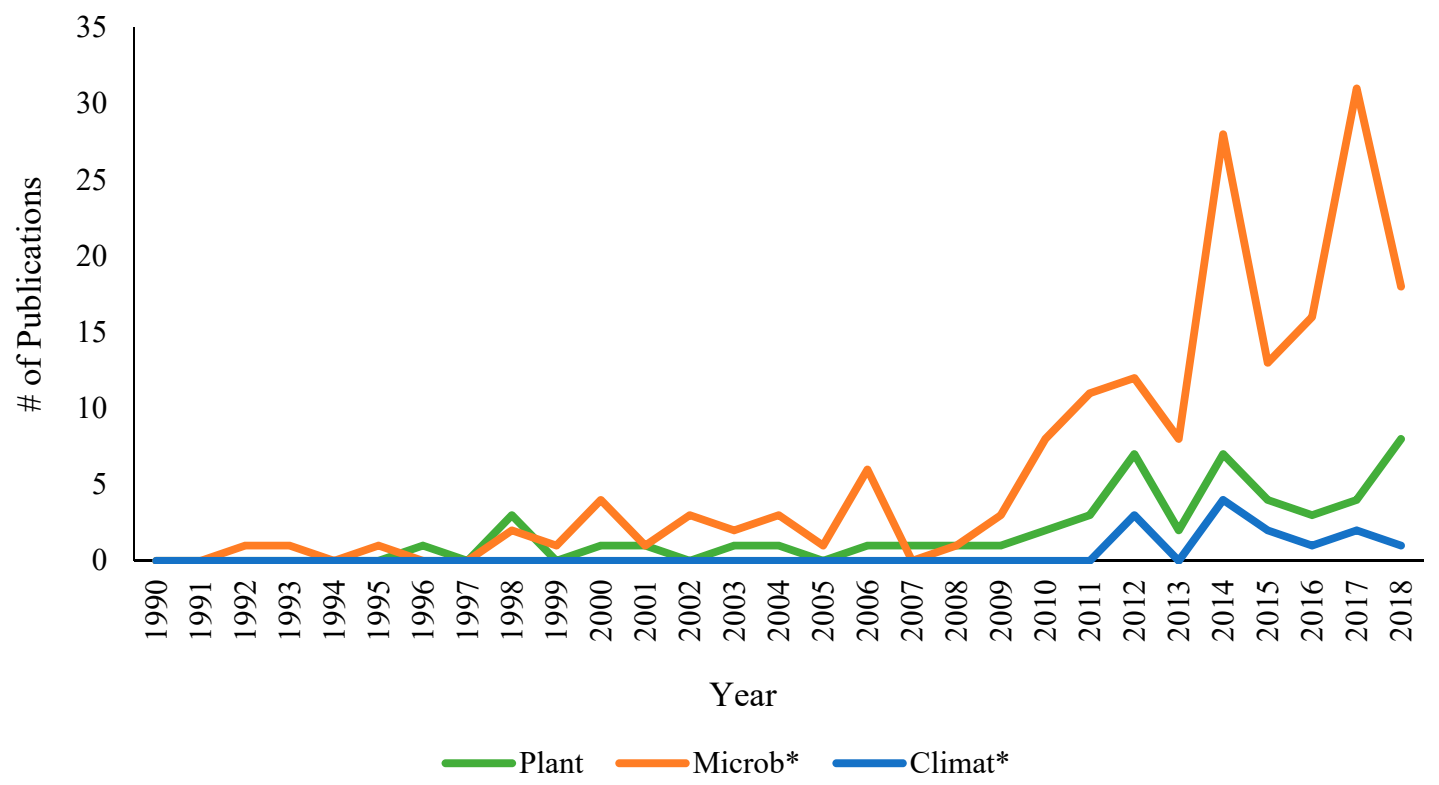

Figure 4. Nitrous oxide reductase-related publications released since 1990 on Web of Science (Clarivate Analytics). Publications by key word vs "nitrous oxide reductase" from 1990 to 2018. The orange line indicates "nitrous oxide reductase" + "microb"”; green: "nitrous oxide reductase" + "plant"; blue: "nitrous oxide reductase" + "climat".

\section{Catch Me If You Can: Can Plants Catalytically Convert $\mathrm{N}_{2} \mathrm{O}$ in planta?}

Rather than a 'cat and robin redbreast' conundrum, we are confronted with an opportunity to deploy protein engineering to ensure that more $\mathrm{N}_{2} \mathrm{OR}$ molecules are attracted to the substrate binding site of the copper enzyme. Protein engineering offers ways to sidestep the challenges of expressing a complex bacterial protein in a plant [110]. There are potential issues with a recombinant metalloprotein like $\mathrm{N}_{2} \mathrm{OR}$, such as whether the $\mathrm{ABC}$ transporter can assemble within a plant cell, or the plant can incorporate copper into the electron transferring and catalytic domains [111,112]. It is possible to re-engineer $\mathrm{N}_{2} \mathrm{OR}$ and produce a functional product [66], so there is precedent for designing an artificial metalloenzyme through rational protein design. This approach may be key to engineering a plant-compatible $\mathrm{N}_{2} \mathrm{OR}$ protein.

A principle challenge associated with imparting $\mathrm{N}_{2} \mathrm{OR}$ functionality to plants is that transforming the nosZ sequence alone may not be effective [113]; in P. stutzeri, the transcription of nos $Z$ was dependent on the nosDFY genes being expressed, as they encode components of a putative $A B C$ transporter system for the biogenesis of the $\mathrm{Cu}_{Z}$ centre [114]. Therefore, catalytically active $\mathrm{N}_{2} \mathrm{OR}$ may not be produced when only nos $Z$ is expressed in a heterologous host [28]. Nevertheless, a model $\mathrm{N}_{2} \mathrm{O}$-expressing plant has been engineered [64,93]. The clade I nos $\mathrm{Z}$ gene from soil bacterium Pseudomonas stutzeri was successfully expressed in a heterologous system-in this case, the tobacco plant (Nicotiana tabacum). In those proof-of-concept experiments the nosZ-expressing tobacco plants reduced $826 \mu \mathrm{g} \mathrm{N} \mathrm{N}_{2} \mathrm{O} / \mathrm{min} /$ gram of leaf tissue [115]. Assuming the tobacco yield to be 0.50 tonne/ha [116], the calculated $\mathrm{N}_{2} \mathrm{O}$-cracking ability of the nosZ-expressing tobacco could be as high as $600 \mathrm{~kg}$ of $\mathrm{N}_{2} \mathrm{O} / \mathrm{ha}$ / day [115], or 60 tonnes/ha/year (100 day growing season). This value surpasses the calculated $\mathrm{N}_{2} \mathrm{O}$ flux of $0.05-1.98 \mathrm{~kg} \mathrm{~N}_{2} \mathrm{O} / \mathrm{ha} /$ year [117]. In other words, if every tobacco plant in the world produced $\mathrm{N}_{2} \mathrm{OR}$, this industrial crop (6.6 million tonnes were produced worldwide in 2016 [118]) could conceivably crack $785 \mathrm{Tg}$ of $\mathrm{N}_{2} \mathrm{O}$ ( $1 \mathrm{Tg}=1$ million metric tonnes) during an average growing season of 100 days, far surpassing the estimated $\sim 30 \mathrm{Tg}$ of $\mathrm{N}_{2} \mathrm{O}$ emitted per year [119]. Such catalytic capacity would give the 'Stop Smoking' campaigns a whole new flavour. 
Although these transgenic plants produced a functional $\mathrm{N}_{2} \mathrm{OR}$ enzyme, no gas analysis was performed to quantifiably ensure that these plants could reduce $\mathrm{N}_{2} \mathrm{O}$ to $\mathrm{N}_{2}$ using a recombinant $\mathrm{N}_{2} \mathrm{OR}$. In the future, it is imperative that such analyses be performed to properly judge the efficacy of such a gene-stacking trait system for atmospheric phytoremediation.

An associated issue rests with $P$. stutzeri being an anaerobic species that produces enzymes that function optimally in a low-oxygen environment. While expressing nos $Z$ in plants to reduce $\mathrm{N}_{2} \mathrm{O}$ appears to be an elegant solution, the $\mathrm{N}_{2} \mathrm{OR}$ enzyme was not evolutionarily engineered to be functional in the presence of oxygen. Most soil bacteria that produce $\mathrm{N}_{2} \mathrm{OR}$ do so in an anaerobic environment [102].

In the past five years, studies have identified several prokaryotic species that may express an oxygen-compatible $\mathrm{N}_{2} \mathrm{OR}$. Aerobic $\mathrm{N}_{2} \mathrm{O}$ reducers may be undertaking an important role in mitigating the amounts of $\mathrm{N}_{2} \mathrm{O}$ emitted to the atmosphere in events of oxic-to-anoxic transitions, but these systems have not yet been validated in plants. Here, we discuss two candidates for an oxygen-compatible nosZ expression system: clade II-nosZ member Gemmatimonas aurantiaca gen nov., spp. nov. strain T-27, a polyphosphate-accumulating soil aerobe that is strongly represented in many oxygen-rich soil samples [120]; and Azospira oryzae, another clade II N-fixing bacterium originally isolated from the roots of rice (Oryza sativa) [121]. $\mathrm{N}_{2} \mathrm{O}$ reduction by the G. aurantiaca strain T-27 was observed in both the absence and presence of oxygen [120]. The inability of this organism to consume $\mathrm{N}_{2} \mathrm{O}$ in the complete absence of oxygen and the observed oxygen-induced activation of nos $Z$ expression compels one to consider in planta overexpression, whereby the diurnal fluctuation of photosynthetic oxygen production may offer an egress for $\mathrm{N}_{2} \mathrm{O}$ accumulation. The A. oryzae strains I09 and I13 also show more rapid $\mathrm{N}_{2} \mathrm{OR}$ recovery rates and tolerance against oxygen inhibition than $P$. stutzeri [121] and so may be appropriate candidates for crop plant transformation and $\mathrm{N}_{2} \mathrm{OR}$ expression.

If the ideal nos $Z$ sequence were to be identified and transformed into commercially important crop plants, the benefits would be numerous and profound: seed-borne GHG technology foresees the transgenic cassette passed on from generation to generation, meaning that constant application of the beneficial catalyst would not be required (as with NI application and rhizoremediation); the expression of nos $\mathrm{Z}$ in the aerial tissues of the plants allows the reducing enzyme to confront $\mathrm{N}_{2} \mathrm{O}$ much more easily than when the enzyme is expressed in the soil.

\section{Novel Breeding Task: “Gas Cracking” Plants}

The challenge of expressing heterologous bacterial proteins in plants necessitates codon optimization due to differences in GC content and codon bias with eukaryotes [122]. Altering the codon bias (or applying 'directed evolution' [123]) of a bacterial gene to be expressed in plants has been highly successful: P. stutzeri nosZ in tobacco [115], 5-enolpyruvylshikimate-3-phosphate (EPSP) synthase from Agrobacterium tumefaciens in Roundup Ready crops [124], and Bacillus thuringiensis Cry genes in maize [125] and rice [126]. Indeed, the global advance promulgating engineered crops is pillared on today's artificial intelligence-guided plant codon optimization rules offered by both large and small boutique DNA houses. However, there has been success expressing native bacterial sequences in plants, i.e., in the case of cotton expressing the native sequence of the $P$. stutzeri gene $p t x d$ (PHOSPHONATE DEHYDROGENASE) $[127,128]$. One can dare to fathom how a universally-functional nos Z expression system could conceivably redirect some aspects of GHG mitigation research. Such a plant transformation cassette could theoretically be applied to any plant-wheat, rice, soybean, peat moss [129] —recruiting these species for the purpose of denitrification mitigation.

Even with an effective nos $Z$ expression system, there are additional challenges in developing nosZ-expressing plant lines. There are relatively few powerful monocot-optimized expression systems available [130] (although Bt corn, LibertyLink wheat, and Roundup Ready wheat can attest to the effectiveness of the $35 \mathrm{~S}$ promoter system in monocots), and there is difficulty in transforming monocots [65]. With the advent of new plant transformation technologies like the soil bacterium 
Ochrobactrum haywardense [131] and the BABYBOOM/WUSCHEL2 system [132], the production of genetically modified crops with stacked or pyramided GHG genes may be expedited in the near future.

\section{Conclusions-Challenges to the Future Success of nosZ}

We must address what may be the greatest challenge of all for the modern molecular plant breeder: convincing the general public that transgenic crops may be beneficial for all the plant-planet's denizens, as modified crops that enter the food stream may appear unpopular in some boroughs. Regardless, there is a clear, urgent need to control soil $\mathrm{N}_{2} \mathrm{O}$ losses due to the detrimental effects of this potent GHG in the atmosphere. Climate-smart crops should be given a crack at directly addressing this issue and tackling climate change. Such GHG-reducing plant lines, endowed with the ability to catalytically "crack" $\mathrm{N}_{2} \mathrm{O}$ in the air, could be vital in the battle to shift public perception towards the acceptance of "GMOs" in agricultural research.

Involvement of $\mathrm{N}_{2} \mathrm{O}$ in climate change and global warming has been the subject of increasing investigations due to its potential heat-trapping properties [3]. $\mathrm{N}_{2} \mathrm{O}$ emission from soil is primarily the result of an incomplete enzymatic reaction which is mediated by the bacterial enzyme, $\mathrm{N}_{2} \mathrm{OR}$ [98] . Therefore, in the late 1990s $[105,106]$, the development of $\mathrm{N}_{2}$ OR-positive transgenic plants was proposed as an environmental phytoremediation strategy with promise to remove $\mathrm{N}_{2} \mathrm{O}$ from soil and the atmosphere (Figure 2). However, producing a foreign protein in a plant cell is often a serious challenge. For example, different codon usage [133] and cellular properties between eukaryotic and prokaryotic cells are considered as unknown aspects of this strategy. At least two key questions need to be addressed in future studies to probe the probability for success of this green gene de-toxic tactic for accelerating the destruction of nitrous oxide via canopy catalysis: (1) Which candidate is the best source-organism to donate nos $\mathrm{Z}$ sequence for plant transformation? Activity of bacterial $\mathrm{N}_{2} \mathrm{OR}$ is associated with the anaerobic conditions in soil [101], whereas the plant cell is mostly an aerobic environment. Photosynthesis and respiration cause different levels of oxygen content in plant cells in a diurnal cycle which is not consistent with the enzymatic activity of $\mathrm{N}_{2} \mathrm{OR}$ in anaerobic soil bacteria. Therefore, selecting obligate or facultative aerobic bacteria containing active $\mathrm{N}_{2} \mathrm{OR}$ enzymes as 'the source code' would be pivotal; (2) Which plant cell compartment is the best destination for targeting $\mathrm{N}_{2} \mathrm{OR}$ accumulation? The native enzyme $\mathrm{N}_{2} \mathrm{OR}$ in bacteria is directed to the periplasm, where $\mathrm{Cu}$ chaperones provide enough $\mathrm{Cu}$ for the assembly of metal centres [134]. The absence of periplasmic space in plant cells reinforces the notion that subcellular localization of $\mathrm{N}_{2} \mathrm{OR}$ may influence its enzymatic activity in planta. Moreover, the important role of $\mathrm{Cu}$ in the functional assembly of $\mathrm{N}_{2} \mathrm{OR}$ posits whether the transformation of bacterial nosDFY, along with nosZ, is essential for a functional enzyme. Urgent exploration of how the cellular pool of metal nutrients and proteins (pseudo chaperones) in eukaryotic cells may suffice to activate $\mathrm{N}_{2} \mathrm{OR}$ in planta may compel the use of such climate-smart plants.

Author Contributions: J.J.D. constructed the initial paper draft; Q.-y.S., J.J.D., S.W., A.E.H., M.N., and I.A. contributed to study design and data analysis; J.J.D., S.W., and I.A. wrote the paper with input from A.E.H., and M.N.; M.N. constructed Figure 2; Q.-y.S. conceptualized the original approach to amplifying soil denitrification in planta; I.A. coordinated and supervised the project; all authors contributed to and approved the final draft.

Funding: This research was funded by a grant from the Government of Ontario in 2018. Q.-Y.S. is a grateful recipient of The Rockefeller Foundation's Career Biotechnology Fellowship.

Acknowledgments: We thank three anonymous reviewers for taking the time to critique and strengthen this manuscript. We are grateful to Quinn Ingram for technical expertise with plant growth.

Conflicts of Interest: The authors declare no competing interests.

\section{References}

1. Dentener, F.; Drevet, J.; Lamarque, J.F. Nitrogen and sulfur deposition on regional and global scales: A multimodel evaluation. Glob. Biogeochem. Cycles 2006, 20,1-21. [CrossRef] 
2. Vet, R.; Artz, R.S.; Carou, S. A global assessment of precipitation chemistry and deposition of sulfur, nitrogen, sea salt, base cations, organic acids, acidity and pH, and phosphorus. Atmos. Environ. 2014, 93, 3-100. [CrossRef]

3. Forster, P.; Ramaswamy, V. Changes in Atmospheric Constituents and in Radiative Forcing; Solomon, S.Q.D., Manning, M., Chen, Z., Marquis, M., Averyt, K.B., Tignor, M., Miller, H.L., Eds.; Cambridge University Press: Cambridge, UK, 2007; pp. 129-234.

4. Reay, D.S. Fertilizer 'solution' could turn local problem global. Nature 2004, 427, 485. [CrossRef] [PubMed]

5. Shapiro, C.A.; Ferguson, R.B.; Hergert, G.W.; Wortmann, C.S.; Walters, D.T. Fertilizer Suggestions for Corn; EC117; Nebraska Extension: Lincoln, NE, USA, 2008; pp. 1-6.

6. Froment, M.A.; Chalmers, A.G.; Collins, C.; Grylls, J.P. Rotational set-aside; influence of vegetation and management for one-year plant covers on soil mineral nitrogen during and after set-aside at five sites in England. J. Agric. Sci. 1999. [CrossRef]

7. Quinton, J.N.; Govers, G.; Van Oost, K.; Bardgett, R.D. The impact of agricultural soil erosion on biogeochemical cycling. Nat. Geosci. 2010, 3, 311-314. [CrossRef]

8. Zhu, Z.L.; Cai, G.X.; Simpson, J.R.; Zhang, S.L.; Chen, D.L.; Jackson, A.V.; Freney, J.R. Processes of nitrogen loss from fertilizers applied to flooded rice fields on a calcareous soil in north-central China. Fertil. Res. 1988, 18, 101-115. [CrossRef]

9. Zhou, M.; Zhu, B.; Brüggemann, N.; Dannenmann, M.; Wang, Y.; Butterbach-Bahl, K. Sustaining crop productivity while reducing environmental nitrogen losses in the subtropical wheat-maize cropping systems: A comprehensive case study of nitrogen cycling and balance. Agric. Ecosyst. Environ. 2016, 231, 1-14. [CrossRef]

10. Zumft, W.G. Cell biology and molecular basis of denitrification. Microbiol. Mol. Biol. Rev. 1997, 61, 533-616. [PubMed]

11. Gu, B.; Chang, J.; Min, Y.; Ge, Y.; Zhu, Q.; Galloway, J.N.; Peng, C. The role of industrial nitrogen in the global nitrogen biogeochemical cycle. Sci. Rep. 2013, 3, 2579. [CrossRef] [PubMed]

12. Erisman, J.W.; Sutton, M.A.; Galloway, J.; Klimont, Z.; Winiwarter, W. How a century of ammonia synthesis changed the world. Nat. Geosci. 2008, 1, 636-639. [CrossRef]

13. Fowler, D.; Pyle, J.A.; Raven, J.A.; Sutton, M.A. The global nitrogen cycle in the twenty-first century: Introduction. Philos. Trans. R. Soc. Lond. B Biol. Sci. 2013, 368, 20130164. [CrossRef] [PubMed]

14. Kanakidou, M.; Myriokefalitakis, S.; Daskalakis, N.; Fanourgakis, G.; Nenes, A.; Baker, A.R.; Tsigaridis, K.; Mihalopoulos, N. Past, present, and future atmospheric nitrogen deposition. J. Atmos. Sci. 2016, 73, 2039-2047. [CrossRef]

15. Richardson, D.; Felgate, H.; Watmough, N.; Thomson, A.; Baggs, E. Mitigating release of the potent greenhouse gas $\mathrm{N}_{2} \mathrm{O}$ from the nitrogen cycle-Could enzymic regulation hold the key? Trends Biotechnol. 2009, 27, 388-397. [CrossRef] [PubMed]

16. Burney, J.A.; Davis, S.J.; Lobell, D.B. Greenhouse gas mitigation by agricultural intensification. Proc. Natl. Acad. Sci. USA 2010, 107, 12052-12057. [CrossRef] [PubMed]

17. Dignon, J.; Hameed, S. Global emissions of nitrogen and sulfur-oxides from 1860 to 1980. Japca 1989, 39, 180-186. [CrossRef]

18. Larsson, L.; Ferm, M.; Kasimir-Klemedtsson, A.; Klemedtsson, L. Ammonia and nitrous oxide emissions from grass and alfalfa mulches. Nutr. Cycl. Agroecosyst. 1998, 51, 41-46. [CrossRef]

19. Intergovernmental Panel on Climate Change. Climate Change 2014: Mitigation of Climate Change; Working Group III Contribution to the IPCC Fifth Assessment Report. 9781107654815; Cambridge University Press: Cambridge, UK, 2015.

20. Ravishankara, A.R.; Daniel, J.S.; Portmann, R.W. Nitrous oxide $\mathrm{N}_{2} \mathrm{O}$ : The dominant ozone-depleting substance emitted in the 21st century. Science 2009, 326, 123-125. [CrossRef] [PubMed]

21. Chen, Z.; Ding, W.; Xu, Y.; Müller, C.; Rütting, T.; Yu, H.; Fan, J.; Zhang, J.; Zhu, T. Importance of heterotrophic nitrification and dissimilatory nitrate reduction to ammonium in a cropland soil: Evidences from a $15 \mathrm{~N}$ tracing study to literature synthesis. Soil Biol. Biochem. 2015, 91, 65-75. [CrossRef]

22. Ruser, R.; Schulz, R. The effect of nitrification inhibitors on the nitrous oxide $\left(\mathrm{N}_{2} \mathrm{O}\right)$ release from agricultural soils-A review. J. Plant Nutr. Soil Sci. 2015, 178, 171-188. [CrossRef]

23. Lees, H. Hydroxylamine as an intermediate in nitrification. Nature 1952, 169, 156-157. [CrossRef] 
24. Caranto, J.D.; Lancaster, K.M. Nitric oxide is an obligate bacterial nitrification intermediate produced by hydroxylamine oxidoreductase. Proc. Natl. Acad. Sci. USA 2017, 114, 8217-8222. [CrossRef] [PubMed]

25. Cébron, A.; Garnier, J. Nitrobacter and Nitrospira genera as representatives of nitrite-oxidizing bacteria: Detection, quantification and growth along the lower Seine River (France). Water Res. 2005, 39, 4979-4992. [CrossRef] [PubMed]

26. Shaw, L.J.; Nicol, G.W.; Smith, Z.; Fear, J.; Prosser, J.I.; Baggs, E.M. Nitrosospira spp. can produce nitrous oxide via a nitrifier denitrification pathway. Environ. Microbiol. 2006, 8, 214-222. [CrossRef] [PubMed]

27. Kole, M.M.; Page, W.J.; Altosaar, I. Distribution of Azotobacter in Eastern Canadian soils and in association with plant rhizospheres. Can. J. Microbiol. 1988, 34, 815-817. [CrossRef]

28. Philippot, L.; Andert, J.; Jones, C.M.; Bru, D.; Hallin, S. Importance of denitrifiers lacking the genes encoding the nitrous oxide reductase for $\mathrm{N}_{2} \mathrm{O}$ emissions from soil. Glob. Chang. Biol. 2011, 17, 1497-1504. [CrossRef]

29. Zumft, W.G.; Kroneck, P.M.H. Respiratory transformation of nitrous oxide $\left(\mathrm{N}_{2} \mathrm{O}\right)$ to dinitrogen by Bacteria and Archaea. Adv. Microb. Physiol. 2007, 52, 107-227. [PubMed]

30. Brodsky, J.B.; Cohen, E.N. Adverse effects of nitrous oxide. Med. Toxicol. 1986, 1, 362-374. [CrossRef] [PubMed]

31. Fluegge, K. Does environmental exposure to the greenhouse gas, $\mathrm{N}_{2} \mathrm{O}$, contribute to etiological factors in neurodevelopmental disorders? A mini-review of the evidence. Environ. Toxicol. Pharmacol. 2016, 47, 6-18. [CrossRef] [PubMed]

32. Edgerton, M.D. Increasing crop productivity to meet global needs for feed, food, and fuel. Plant Physiol. 2009, 149, 7-13. [CrossRef] [PubMed]

33. Abalos, D.; van Groenigen, J.W.; De Deyn, G.B. What plant functional traits can reduce nitrous oxide emissions from intensively managed grasslands? Glob. Chang. Biol. 2018, 24, e248-e258. [CrossRef] [PubMed]

34. Terman, G.L. Volatilization losses of nitrogen as ammonia from surface-applied fertilizers, organic amendments, and crop residues. Adv. Agron. 1980, 31, 189-223.

35. Holcomb, J.C.; Sullivan, D.M.; Horneck, D.A.; Clough, G.H. Effect of irrigation rate on ammonia volatilization. Soil Sci. Soc. Am. J. 2011, 75, 2341-2347. [CrossRef]

36. Van Kessel, C.; Venterea, R.; Six, J.; Adviento-Borbe, M.A.; Linquist, B.; van Groenigen, K.J. Climate, duration, and $\mathrm{N}$ placement determine $\mathrm{N}_{2} \mathrm{O}$ emissions in reduced tillage systems: A meta-analysis. Glob. Chang. Biol. 2013, 19, 33-44. [CrossRef] [PubMed]

37. Mei, K.; Wang, Z.; Huang, H.; Zhang, C.; Shang, X.; Dahlgren, R.A.; Zhang, M.; Xia, F. Stimulation of $\mathrm{N}_{2} \mathrm{O}$ emission by conservation tillage management in agricultural lands: A meta-analysis. Soil Till. Res. 2018, 182, 86-93. [CrossRef]

38. Pittelkow, C.M.; Liang, X.; Linquist, B.A.; van Groenigen, K.J.; Lee, J.; Lundy, M.E.; van Gestel, N.; Six, J.; Venterea, R.T.; van Kessel, C. Productivity limits and potentials of the principles of conservation agriculture. Nature 2015, 517, 365-368. [CrossRef] [PubMed]

39. Bruulsema, T.; Lemunyon, J.; Herz, B. Know your fertilizer rights. Crops Sci. 2009, 42, 13-18.

40. Bruulsema, T.W.; Ketterings, Q. Best Management Practices for Fertilizers on Northeastern Dairy Farms; Fertilize BMP Item 30-3220; Ref. 08052; International Plant Nutrition Institute: Norcross, GA, USA, 2008.

41. Guardia, G.; Cangani, M.T.; Andreu, G.; Sanz-Cobena, A.; García-Marco, S.; Álvarez, J.M.; Recio-Huetos, J.; Vallejo, A. Effect of inhibitors and fertigation strategies on GHG emissions, NO fluxes and yield in irrigated maize. Field Crops Res. 2017, 204, 135-145. [CrossRef]

42. Cayuela, M.L.; Aguilera, E.; Sanz-Cobena, A.; Adams, D.C.; Abalos, D.; Barton, L.; Ryals, R.; Silver, W.L.; Alfaro, M.A.; Pappa, V.A.; et al. Direct nitrous oxide emissions in Mediterranean climate cropping systems: Emission factors based on a meta-analysis of available measurement data. Agric. Ecosyst. Environ. 2017, 238, 25-35. [CrossRef]

43. Sanz-Cobena, A.; Lassaletta, L.; Aguilera, E.; Del Prado, A.; Garnier, J.; Billen, G.; Iglesias, A.; Sanchez, B.; Guardia, G.; Abalos, D.; et al. Strategies for greenhouse gas emissions mitigation in Mediterranean agriculture: A review. Agric. Ecosyst. Environ. 2017, 238, 5-24. [CrossRef]

44. Hynes, R.; Knowles, R. Production of nitrous oxide by Nitrosomonas europaea: Effects of acetylene, pH, and oxygen. Can. J. Microbiol. 2011, 30, 1397-1404. [CrossRef]

45. Halvorson, A.D.; Snyder, C.S.; Blaylock, A.D.; Del Grosso, S.J. Enhanced-efficiency nitrogen fertilizers: Potential role in nitrous oxide emission mitigation. Agron. J. 2014, 106, 715-722. [CrossRef] 
46. Thapa, R.; Chatterjee, A.; Awale, R.; McGranahan, D.A.; Daigh, A. Effect of enhanced efficiency fertilizers on nitrous oxide emissions and crop yields: A meta-analysis. Soil Sci. Soc. Am. J. 2016, 80, 1121-1134. [CrossRef]

47. Shoji, S.; Delgado, J.; Mosier, A.; Miura, Y. Use of controlled release fertilizers and nitrification inhibitors to increase nitrogen use efficiency and to conserve air and water quality. Commun. Soil Sci. Plant Anal. 2001, 32, 1051-1070. [CrossRef]

48. McTaggart, I.P.; Tsuruta, H. The influence of controlled release fertilisers and the form of applied fertiliser nitrogen on nitrous oxide emissions from an andosol. Nutr. Cycl. Agroecosyst. 2003, 67, 47-54. [CrossRef]

49. Sanz-Cobena, A.; Abalos, D.; Meijide, A.; Sanchez-Martin, L.; Vallejo, A. Soil moisture determines the effectiveness of two urease inhibitors to decrease $\mathrm{N}_{2} \mathrm{O}$ emission. Mitig. Adapt. Strateg. Glob. Chang. 2016, 21, 1131-1144. [CrossRef]

50. Kim, M.; Zhang, Z.; Okano, H.; Yan, D.; Groisman, A.; Hwa, T. Need-based activation of ammonium uptake in Escherichia coli. Mol. Syst. Biol. 2012, 8, 616. [CrossRef] [PubMed]

51. Soares, J.; Cantarella, H.; Menegale, M. Ammonia volatilization losses from surface-applied urea with urease and nitrification inhibitors. Soil Biol. Biochem. 2012, 52, 82-89. [CrossRef]

52. McCarty, G.W. Modes of action of nitrification inhibitors. Biol. Fertil. Soils 1999, 29, 1-9. [CrossRef]

53. Liu, C.; Wang, K.; Zheng, X. Effects of nitrification inhibitors (DCD and DMPP) on nitrous oxide emission, crop yield and nitrogen uptake in a wheat-maize cropping system. Biogeosciences 2013, 10, 2427-2437. [CrossRef]

54. Bollag, J.-M.; Kurek, E.J. Nitrite and nitrous oxide accumulation during denitrification in the presence of pesticide derivatives. Appl. Environ. Microbiol. 1980, 39, 845-849. [PubMed]

55. Lam, S.K.; Suter, H.; Mosier, A.R.; Chen, D. Using nitrification inhibitors to mitigate agricultural $\mathrm{N}_{2} \mathrm{O}$ emission: A double-edged sword? Glob. Chang. Biol. 2016, 23, 485-489. [CrossRef] [PubMed]

56. Subbarao, G.V.; Nakahara, K.; Hurtado, M.P.; Ono, H.; Moreta, D.E.; Salcedo, A.F.; Yoshihashi, A.T.; Ishikawa, T.; Ishitani, M.; Ohnishi-Kameyama, M.; et al. Evidence for biological nitrification inhibition in Brachiaria pastures. Proc. Natl. Acad. Sci. USA 2009, 106, 17302. [CrossRef] [PubMed]

57. Bardon, C.; Poly, F.; Piola, F.; Pancton, M.; Comte, G.; Meiffren, G.; Haichar Fel, Z. Mechanism of biological denitrification inhibition: Procyanidins induce an allosteric transition of the membrane-bound nitrate reductase through membrane alteration. FEMS Microbiol. Ecol. 2016, 92, fiw034. [CrossRef] [PubMed]

58. Subbarao, G.V.; Sahrawat, K.L.; Nakahara, K.; Rao, I.M.; Ishitani, M.; Hash, C.T.; Kishii, M.; Bonnett, D.G.; Berry, W.L.; Lata, J.C. A paradigm shift towards low-nitrifying production systems: The role of biological nitrification inhibition (BNI). Ann. Bot. 2013, 112, 297-316. [CrossRef] [PubMed]

59. Jacinthe, P.-A.; Dick, W.A.; Brown, L.C. Bioremediation of nitrate-contaminated shallow soils and waters via water table management techniques: Evolution and release of nitrous oxide. Soil Biol. Biochem. 2000, 32, 371-382. [CrossRef]

60. Itakura, M.; Tabata, K.; Eda, S.; Mitsui, H.; Murakami, K.; Yasuda, J.; Minamisawa, K. Generation of Bradyrhizobium japonicum mutants with Increased $\mathrm{N}_{2} \mathrm{O}$ reductase activity by selection after introduction of a mutated dnaQ gene. Appl. Environ. Microbiol. 2008, 74, 7258-7264. [CrossRef] [PubMed]

61. Itakura, M.; Uchida, Y.; Akiyama, H.; Hoshino, Y.T.; Shimomura, Y.; Morimoto, S.; Tago, K.; Wang, Y.; Hayakawa, C.; Uetake, Y.; et al. Mitigation of nitrous oxide emissions from soils by Bradyrhizobium japonicum inoculation. Nat. Clim. Chang. 2012, 3, 208-212. [CrossRef]

62. Houlden, A.; Timms-Wilson, T.M.; Day, M.J.; Bailey, M.J. Influence of plant developmental stage on microbial community structure and activity in the rhizosphere of three field crops. FEMS Microbiol. Ecol. 2008, 65, 193-201. [CrossRef] [PubMed]

63. Xu, Y.; Wang, G.; Jin, J.; Liu, J.; Zhang, Q.; Liu, X. Bacterial communities in soybean rhizosphere in response to soil type, soybean genotype, and their growth stage. Soil Biol. Biochem. 2009, 41, 919-925. [CrossRef]

64. Wan, S.; Johnson, A.M.; Altosaar, I. Expression of nitrous oxide reductase from Pseudomonas stutzeri in transgenic tobacco roots using the root-specific rolD promoter from Agrobacterium rhizogenes. Ecol. Evol. 2012, 2, 286-297. [CrossRef] [PubMed]

65. Sood, P.; Bhattacharya, A.; Sood, A. Problems and possibilities of monocot transformation. Biol. Plant 2011, 55, 1-15. [CrossRef]

66. Matsubara, T.; Frunzke, K.; Zumft, W.G. Modulation by copper of the products of nitrite respiration in Pseudomonas perfectomarinus. Biol. Fertil. Soils 1982, 149, 816-823. 
67. Wan, S.; Ward, T.L.; Altosaar, I. Strategy and tactics of disarming GHG at the source: $\mathrm{N}_{2} \mathrm{O}$ reductase crops. Trends Biotechnol. 2012, 30, 410-415. [CrossRef] [PubMed]

68. Rochette, P.; Angers, D.A.; Chantigny, M.H.; Gasser, M.-O.; MacDonald, J.D.; Pelster, D.E.; Bertrand, N. $\mathrm{NH}_{3}$ volatilization, soil concentration and soil $\mathrm{pH}$ following subsurface banding of urea at increasing rates. Can. J. Soil Sci. 2013, 93, 261-268. [CrossRef]

69. Venterea, R.T.; Burger, M.; Spokas, K.A. Nitrogen oxide and methane emissions under varying tillage and fertilizer management. J. Environ. Qual. 2005, 34, 1467-1477. [CrossRef] [PubMed]

70. Chen, G.; Kolb, L.; Cavigelli, M.A.; Weil, R.R.; Hooks, C.R.R. Can conservation tillage reduce $\mathrm{N}_{2} \mathrm{O}$ emissions on cropland transitioning to organic vegetable production? Sci. Total Environ. 2018, 618, 927-940. [CrossRef] [PubMed]

71. Mitchell, D.C.; Castellano, M.J.; Sawyer, J.E.; Pantoja, J. Cover crop effects on nitrous oxide emissions: Role of mineralizable carbon. Soil Sci. Soc. Am. J. 2013, 77, 1765. [CrossRef]

72. Snyder, C.S.; Bruulsema, T.W.; Jensen, T.L.; Fixen, P.E. Review of greenhouse gas emissions from crop production systems and fertilizer management effects. Agric. Ecosyst. Environ. 2009, 133, 247-266. [CrossRef]

73. Abalos, D.; Jeffery, S.; Sanz-Cobena, A.; Guardia, G.; Vallejo, A. Meta-analysis of the effect of urease and nitrification inhibitors on crop productivity and nitrogen use efficiency. Agric. Ecosyst. Environ. 2014, 189, 136-144. [CrossRef]

74. Cantarella, H.; Otto, R.; Soares, J.R.; Silva, A.G.d.B. Agronomic efficiency of NBPT as a urease inhibitor: A review. J. Adv. Res. 2018, 13, 19-27. [CrossRef] [PubMed]

75. Bremner, J.M. Recent research on problems in the use of urea as a nitrogen fertilizer. Fertil. Res. 1995, 42, 321-329. [CrossRef]

76. Zaman, M.; Zaman, S.; Nguyen, M.L.; Smith, T.J.; Nawaz, S. The effect of urease and nitrification inhibitors on ammonia and nitrous oxide emissions from simulated urine patches in pastoral system: A two-year study. Sci. Total Environ. 2013, 465, 97-106. [CrossRef] [PubMed]

77. Ding, W.X.; Yu, H.Y.; Cai, Z.C. Impact of urease and nitrification inhibitors on nitrous oxide emissions from fluvo-aquic soil in the North China Plain. Biol. Fertil. Soils 2011, 47, 91-99. [CrossRef]

78. Singh, S.; Bakshi, B.R. Accounting for the biogeochemical cycle of nitrogen in input-output life cycle assessment. Environ. Sci. Technol. 2013, 47, 9388-9396. [CrossRef] [PubMed]

79. Rose, T.J.; Quin, P.; Morris, S.G.; Kearney, L.J.; Kimber, S.; Rose, M.T.; Van Zwieten, L. No evidence for higher agronomic $\mathrm{N}$ use efficiency or lower nitrous oxide emissions from enhanced efficiency fertilisers in aerobic subtropical rice. Field Crops Res. 2018, 225, 47-54. [CrossRef]

80. Chaves, B.; Opoku, A.; De Neve, S.; Boeckx, P.; Van Cleemput, O.; Hofman, G. Influence of DCD and DMPP on soil N dynamics after incorporation of vegetable crop residues. Biol. Fertil. Soils 2006, 43, 62-68. [CrossRef]

81. Yang, M.; Fang, Y.; Sun, D.; Shi, Y. Efficiency of two nitrification inhibitors (dicyandiamide and 3,4-dimethypyrazole phosphate) on soil nitrogen transformations and plant productivity: A meta-analysis. Sci. Rep. 2016, 6, 1-10.

82. Coskun, D.; Britto, D.T.; Shi, W.; Kronzucker, H.J. How plant root exudates shape the nitrogen cycle. Trends Plant Sci. 2017, 22, 661-673. [CrossRef] [PubMed]

83. Matsuoka, M.; Kumar, A.; Muddassar, M.; Matsuyama, A.; Yoshida, M.; Zhang, K.Y. Discovery of fungal denitrification inhibitors by targeting copper nitrite reductase from Fusarium oxysporum. J. Chem. Inf. Model. 2017, 57, 203-213. [CrossRef] [PubMed]

84. Liu, T.; Liang, Y.; Chu, G. Nitrapyrin addition mitigates nitrous oxide emissions and raises nitrogen use efficiency in plastic-film-mulched drip-fertigated cotton field. PLoS ONE 2017, 12, e0176305. [CrossRef] [PubMed]

85. Byrnes, R.C.; Nùñez, J.; Arenas, L.; Rao, I.; Trujillo, C.; Alvarez, C.; Arango, J.; Rasche, F.; Chirinda, N. Biological nitrification inhibition by Brachiaria grasses mitigates soil nitrous oxide emissions from bovine urine patches. Soil Biol. Biochem. 2017, 107, 156-163. [CrossRef]

86. Subbarao, G.V.; Arango, J.; Masahiro, K.; Hooper, A.M.; Yoshihashi, T.; Ando, Y.; Nakahara, K.; Deshpande, S.; Ortiz-Monasterio, I.; Ishitani, M.; et al. Genetic mitigation strategies to tackle agricultural GHG emissions: The case for biological nitrification inhibition technology. Plant Sci. Int. J. Exp. Plant Biol. 2017, 262, 165-168. [CrossRef] [PubMed] 
87. Karwat, H.; Moreta, D.; Arango, J.; Núñez, J.; Rao, I.; Rincón, Á.; Rasche, F.; Cadisch, G. Residual effect of BNI by Brachiaria humidicola pasture on nitrogen recovery and grain yield of subsequent maize. Plant Soil. 2017, 420, 389-406. [CrossRef]

88. Kuiper, I.; Lagendijk, E.L.; Bloemberg, G.V.; Lugtenberg, B.J.J. Rhizoremediation: A beneficial plant-microbe interaction. Mol. Plant Microbe Interact. 2004, 17, 6-15. [CrossRef] [PubMed]

89. Qian, J.H.; Doran, J.W.; Weier, K.L.; Mosier, A.R.; Peterson, T.A.; Power, J.F. Soil denitrification and nitrous oxide losses under corn irrigated with high-nitrate groundwater. J. Environ. Qual. 1997, 26, 348-360. [CrossRef]

90. Köpke, U.; Nemecek, T. Ecological services of faba bean. Field Crops Res. 2010, 115, 217-233. [CrossRef]

91. Gaume, A.; Komarnytsky, S.; Borisjuk, N.; Raskin, I. Rhizosecretion of recombinant proteins from plant hairy roots. Plant Cell Rep. 2003, 21, 1188-1193. [CrossRef] [PubMed]

92. Gelvin, S.B. Crown gall disease and hairy root disease. Plant Physiol. 1990, 92, 281-285. [CrossRef] [PubMed]

93. Wan, S.; Mottiar, Y.; Johnson, A.M.; Goto, K.; Altosaar, I. Expression of the nos operon proteins from Pseudomonas stutzeri in transgenic plants to assemble nitrous oxide reductase. Transgenic Res. 2012, 21, 593-603. [CrossRef] [PubMed]

94. French, C.E.; Rosser, S.J.; Davies, G.J.; Nicklin, S.; Bruce, N.C. Biodegradation of explosives by transgenic plants expressing pentaerythritol tetranitrate reductase. Nat. Biotechnol. 1999, 17, 491-494. [CrossRef] [PubMed]

95. Rugh, C.L.; Wilde, H.D.; Stack, N.M.; Thompson, D.M.; Summers, A.O.; Meagher, R.B. Mercuric ion reduction and resistance in transgenic Arabidopsis thaliana plants expressing a modified bacterial merA gene. Proc. Natl. Acad. Sci. USA 1996, 93, 3182-3187. [CrossRef] [PubMed]

96. Nahar, N.; Rahman, A.; Nawani, N.N.; Ghosh, S.; Mandal, A. Phytoremediation of arsenic from the contaminated soil using transgenic tobacco plants expressing ACR2 gene of Arabidopsis thaliana. J. Plant Physiol. 2017, 218, 121-126. [CrossRef] [PubMed]

97. Heaton, A.C.P.; Rugh, C.L.; Wang, N.J.; Meagher, R.B. Phytoremediation of mercury- and methylmercury-polluted soils using genetically engineered plants. Soil Sediment Contam. 1998, 7, 497-509. [CrossRef]

98. Maeda, K.; Hanajima, D.; Toyoda, S.; Yoshida, N.; Morioka, R.; Osada, T. Microbiology of nitrogen cycle in animal manure compost. Microb. Biotechnol. 2011. [CrossRef] [PubMed]

99. Sanford, R.A.; Wagner, D.D.; Wu, Q.; Chee-Sanford, J.C.; Thomas, S.H.; Cruz-Garcia, C.; Rodriguez, G.; Massol-Deya, A.; Krishnani, K.K.; Ritalahti, K.M.; et al. Unexpected nondenitrifier nitrous oxide reductase gene diversity and abundance in soils. Proc. Natl. Acad. Sci. USA 2012, 109, 19709-19714. [CrossRef] [PubMed]

100. Yoon, S.; Nissen, S.; Park, D.; Sanford, R.A.; Löffler, F.E. Nitrous oxide reduction kinetics distinguish bacteria harboring clade I NosZ from those harboring clade II NosZ. Appl. Environ. Microbiol. 2016, 82, 3793-3800. [CrossRef] [PubMed]

101. Cuypers, H.; Berghofer, J.; Zumft, W.G. Multiple nosZ promoters and anaerobic expression of nos genes necessary for Pseudomonas stutzeri nitrous oxide reductase and assembly of its copper centers. Biochim. Biophys. Acta 1995, 1264, 183-190. [CrossRef]

102. Rosenzweig, A.C. Nitrous oxide reductase from $\mathrm{Cu}_{\mathrm{A}}$ to Cu . Nat. Struct. Biol. 2000, 7, 169-171. [CrossRef] [PubMed]

103. Wang, Y.; Wang, Z.; Duo, Y.; Wang, X.; Chen, J.; Chen, J. Gene cloning, expression, and reducing property enhancement of nitrous oxide reductase from Alcaligenes denitrificans strain TB. Environ. Pollut. 2018, 239, 43-52. [CrossRef] [PubMed]

104. Carreira, C.; Pauleta, S.R.; Moura, I. The catalytic cycle of nitrous oxide reductase-The enzyme that catalyzes the last step of denitrification. J. Inorg. Biochem. 2017, 177, 423-434. [CrossRef] [PubMed]

105. Inatomi, K.I. Analysis of the nitrous oxide reduction genes, nosZDFYL, of Achromobacter cycloclastes. DNA Res. 1998, 5, 365-371. [CrossRef] [PubMed]

106. Inatomi, K.-I. Gene Encoding Nitrous Oxide Reductase and the Nitrous Oxide Reductase. Patent Application JP H1175842A, 29 August 1997.

107. Cheng, J.; Romantsov, T.; Engel, K.; Doxey, A.C.; Rose, D.R.; Neufeld, J.D.; Charles, T.C. Functional metagenomics reveals novel $\beta$-galactosidases not predictable from gene sequences. PLoS ONE 2017, 12, e0172545. [CrossRef] [PubMed] 
108. Hill, P.; Heberlig, G.W.; Boddy, C.N. Sampling terrestrial environments for bacterial polyketides. Molecules 2017, 22, E707. [CrossRef] [PubMed]

109. Kolter, R.; Chimileski, S. The end of microbiology. Environ. Microbiol. 2018. [CrossRef] [PubMed]

110. Lin, Y.W. Rational design of metalloenzymes: From single to multiple active sites. Coord. Chem. Rev. 2017, 336, 1-27. [CrossRef]

111. Zumft, W.G. Biogenesis of the bacterial respiratory $\mathrm{Cu}_{\mathrm{A}}, \mathrm{Cu}-\mathrm{S}$ enzyme nitrous oxide reductase. J. Mol. Microbiol. Biotechnol. 2005, 10, 154-166. [CrossRef] [PubMed]

112. Dell'Acqua, S.; Pauleta, S.R.; Moura, I.; Moura, J.J.G. The tetranuclear copper active site of nitrous oxide reductase: The $\mathrm{Cu}_{\mathrm{Z}}$ center. J. Biol. Inorg. Chem. 2011, 16, 183-194. [CrossRef] [PubMed]

113. Kusnadi, A.R.; Nikolov, Z.L.; Howard, J.A. Production of recombinant proteins in transgenic plants: Practical considerations. Biotechnol. Bioeng. 1997, 56, 473-484. [CrossRef]

114. Honisch, U.; Zumft, W.G. Operon structure and regulation of the nos gene region of Pseudomonas stutzeri, encoding an ABC-Type ATPase for maturation of nitrous oxide reductase. J. Bacteriol. 2003, 185, 1895-1902. [CrossRef] [PubMed]

115. Wan, S.; Greenham, T.; Goto, K.; Mottiar, Y.; Johnson, A.M.; Staebler, J.M.; Zaidi, M.A.; Shu, Q.; Altosaar, I. A novel nitrous oxide mitigation strategy: Expressing nitrous oxide reductase from Pseudomonas stutzeri in transgenic plants. Can. J. Plant Sci. 2014, 94, 1013-1023. [CrossRef]

116. Andri, K.B.S.; Santosa, P.; Arifin, Z. An empirical study of supply chain and intensification program on Madura tobacco industry in East Java. Int. J. Agric. Res. 2011, 6, 58-66. [CrossRef]

117. Sgouridis, F.; Ullah, S. Soil greenhouse gas fluxes, environmental controls, and the partitioning of $\mathrm{N}_{2} \mathrm{O}$ sources in UK natural and seminatural land use types. J. Geophys. Res. Biogeosci. 2017, 122, 2617-2633. [CrossRef]

118. FAO. FAOSTAT. 2016; Available online: fao.org.

119. Intergovernmental Panel on Climate Change. Climate Change 2014: Synthesis Report; Contribution of Working Groups I, II and III to the Fifth Assessment Report of the Intergovernmental Panel on Climate Change; Pachauri, R.K., Meyer, L.A., Eds.; Cambridge University Press: Cambridge, UK, 2014.

120. Park, D.; Kim, H.; Yoon, S. Nitrous oxide reduction by an obligate aerobic bacterium, Gemmatimonas aurantiaca strain T-27. Appl. Environ. Microbiol. 2017, 80, e00502-e00517. [CrossRef] [PubMed]

121. Suenaga, T.; Aoyagi, T.; Hosomi, M.; Hori, T.; Terada, A. Draft genome sequence of Azospira sp. strain I13, a nitrous oxide-reducing bacterium harboring clade II type nosZ. Genome Annouc. 2018, 6, e00414-e00418. [CrossRef] [PubMed]

122. Plotkin, J.B.; Kudla, G. Synonymous but not the same: The causes and consequences of codon bias. Nat. Rev. Genet. 2011, 12, 32-42. [CrossRef] [PubMed]

123. Hartley, B.S. Evolution of enzyme structure. Proc. R. Soc. Lond. B Biol. Sci. 1979, 205, 443-452. [CrossRef] [PubMed]

124. Padgette, S.R.; Kolacz, K.H.; Delannay, X.; Re, D.B.; LaVallee, B.J.; Tinius, C.N.; Rhodes, W.K.; Otero, Y.I.; Barry, G.F.; Eichholtz, D.A.; et al. Development, identification, and characterization of a glyphosate-tolerant soybean line. Crop Sci. 1995, 35, 1451-1461. [CrossRef]

125. Sardana, R.; Dukiandjiev, S.; Giband, M.; Cheng, X.; Cowan, K.; Sauder, C.; Altosaar, I. Construction and rapid testing of synthetic and modified toxin gene sequences CryIA $(b \& c)$ by expression in maize endosperm culture. Plant Cell Rep. 1996, 15, 677-681. [PubMed]

126. Cheng, X.; Sardana, R.; Kaplan, H.; Altosaar, I. Agrobacterium-transformed rice plants expressing synthetic $\operatorname{cryI} A(b)$ and $\operatorname{cryI} A(c)$ genes are highly toxic to striped stem borer and yellow stem borer. Proc. Natl. Acad. Sci. USA 1998, 95, 2767-2772. [CrossRef] [PubMed]

127. Pandeya, D.; Campbell, L.A.M.; Nunes, E.; Lopez-Arredondo, D.L.; Janga, M.R.; Herrera-Estrella, L.; Rathore, K.S. ptxD gene in combination with phosphite serves as a highly effective selection system to generate transgenic cotton (Gossypium hirsutum L.). Plant Mol. Biol. 2017, 566-567. [CrossRef] [PubMed]

128. Pandeya, D.; López-Arredondo, D.L.; Janga, M.R.; Campbell, L.M.; Estrella-Hernández, P.; Bagavathiannan, M.V.; Herrera-Estrella, L.; Rathore, K.S. Selective fertilization with phosphite allows unhindered growth of cotton plants expressing the $p t x D$ gene while suppressing weeds. Proc. Natl. Acad. Sci. USA 2018, 115, E6946-E6955. [CrossRef] [PubMed] 
129. Liimatainen, M.; Voigt, C.; Martikainen, P.J.; Hytönen, J.; Regina, K.; Óskarsson, H.; Maljanen, M. Factors controlling nitrous oxide emissions from managed northern peat soils with low carbon to nitrogen ratio. Soil Biol. Biochem. 2018, 122, 186-195. [CrossRef]

130. Park, S.-H.; Yi, N.; Kim, Y.S.; Jeong, M.-H.; Bang, S.-W.; Choi, Y.D.; Kim, J.-K. Analysis of five novel putative constitutive gene promoters in transgenic rice plants. J. Exp. Bot. 2010, 61, 2459-2467. [CrossRef] [PubMed]

131. Anand, A.; Bass, S.H.; Bertain, S.M.; Cho, H.-J.; Kinney, A.J. Ochrobactrum-Mediated Transformation of Plants. US Patent App. WO/2017/040343, 26 August 2016.

132. Hofmann, N.R. A breakthrough in monocot transformation methods. Plant Cell 2016, 28, 1989. [CrossRef] [PubMed]

133. Webster, G.R.; Teh, A.Y.H.; Ma, J.K.C. Synthetic gene design-The rationale for codon optimization and implications for molecular pharming in plants. Biotechnol. Bioeng. 2017, 114, 492-502. [CrossRef] [PubMed]

134. Wunsch, P.; Herb, M.; Wieland, H.; Schiek, U.M.; Zumft, W.G. Requirements for Cu-A and Cu-S center assembly of nitrous oxide reductase deduced from complete periplasmic enzyme maturation in the nondenitrifier Pseudomonas putida. J. Bacteriol. 2003, 185, 887-896. [CrossRef] [PubMed]

(C) 2018 by the authors. Licensee MDPI, Basel, Switzerland. This article is an open access article distributed under the terms and conditions of the Creative Commons Attribution (CC BY) license (http:// creativecommons.org/licenses/by/4.0/). 